Article

\title{
First Report of the Parasitic Nematode Pseudoterranova spp. Found in Mediterranean Monk Seal (Monachus monachus) in Greece: Conservation Implications
}

\author{
Efstathia Koitsanou 1,*, Joanne Sarantopoulou ${ }^{1}$, Anastasia Komnenou ${ }^{2,3}$, Athanasios Exadactylos ${ }^{1}$ (D), \\ Panagiotis Dendrinos ${ }^{4}$, Elias Papadopoulos ${ }^{2}$ (D) and Georgios A. Gkafas ${ }^{1, *}$ (D)
}

Citation: Koitsanou, E.; Sarantopoulou, J.; Komnenou, A.; Exadactylos, A.; Dendrinos, P.; Papadopoulos, E.; Gkafas, G.A. First Report of the Parasitic Nematode Pseudoterranova spp. Found in Mediterranean Monk Seal (Monachus monachus) in Greece: Conservation Implications. Conservation 2022, 2, 122-133. https://doi.org/10.3390/ conservation 2010010

Academic Editor: Antoni Margalida

Received: 28 December 2021

Accepted: 18 February 2022

Published: 23 February 2022

Publisher's Note: MDPI stays neutral with regard to jurisdictional claims in published maps and institutional affiliations.

Copyright: (C) 2022 by the authors. Licensee MDPI, Basel, Switzerland. This article is an open access article distributed under the terms and conditions of the Creative Commons Attribution (CC BY) license (https:// creativecommons.org/licenses/by/ $4.0 /)$.
1 Department of Ichthyology and Aquatic Environment, School of Agricultural Sciences, University of Thessaly, Fytokou Str., 38446 Volos, Greece; saradopo@uth.gr (J.S.); exadact@uth.gr (A.E.)

2 School of Veterinary Medicine, Faculty of Health Sciences, Aristotle University of Thessaloniki, 54124 Thessaloniki, Greece; natakomn@vet.auth.gr (A.K.); eliaspap@vet.auth.gr (E.P.)

3 ARION-Cetacean Rescue and Rehabilitation Research Center, M. Botsari 110, 54453 Thessaloniki, Greece

4 MOm/Hellenic Society for the Study and Protection of the Monk Seal, 10682 Athens, Greece; p.dendrinos@mom.gr

* Correspondence: ekoitsanou@uth.gr (E.K.); gkafas@uth.gr (G.A.G.)

\begin{abstract}
The Mediterranean monk seal (Monachus monachus) is classified as an endangered species by the IUCN, with a global population that does not exceed 800 individuals. There is limited understanding around the biology and health status of the species, rendering possible parasitic infections grave for its conservation efforts. The aim of the current study was the molecular identification of a parasitic nematode found in the digestive system of a sub-adult Mediterranean monk seal individual, that was found stranded in the area of Pagasitikos Gulf, Greece in 2019. Analysis of the stomach contents revealed the presence of two intact female nematode individuals. Standard protocols were followed as DNA extraction of the parasites was conducted and PCR amplification of the cytochrome oxidase subunit I (COI) mitochondrial gene was implemented. Sequencing analysis of a $585 \mathrm{bp}$ amplified product displayed a $96 \%$ similarity of the screened nematodes to the Pseudoterranova bulbosa species. Bayesian inference was implemented for the subsequent tree reconstruction. The phylogenetic tree revealed a clear genetic similarity between our parasitic nematode individuals named as Pseudoterranova spp. and Pseudoterranova bulbosa (bootstrap value: $82 \%$ ), which is indicated for the first and only time as such, to be found in the waters of the Mediterranean Sea and also in the stomach of a Mediterranean monk seal.
\end{abstract}

Keywords: Monachus monachus; parasitic nematode; eastern Mediterranean; COI; molecular identification

\section{Introduction}

The Mediterranean monk seal (Monachus monachus) belongs to the Phocidae family and is considered as an endangered species. Today the world population is separated in three isolated subpopulations [1]; in the Madeira-Desertas Islands (Atlantic Ocean) there are about 30 individuals; in Cape Blanc (Western Sahara) there are 150-200 individuals; and finally in the eastern Mediterranean basin, the largest subpopulation is composed of about 350 individuals in small, scattered groups that are distributed along the Greek coasts and islands and along the Turkish Aegean and Mediterranean coasts [2-7]. Monk seals in Greece have been recorded to travel long distances, for example $\sim 288 \mathrm{~km}$ in three months, with a maximum straight distance travel of $\sim 78 \mathrm{~km}$ [8]. During their movements, it is possible that seals often come in close contact with other species and in some cases with humans (e.g., on cosmopolitan beaches during summer). Thus, seals might become infected by pathogens possibly due to species-level potential mechanics behind transmission and intermediate hosts [9]. 
Since the opening of the Suez Canal, the Mediterranean Sea has been exposed to new marine animal species that mainly migrate from the Red Sea through the canal [10]. Currently, more species of Lessepsian migrators are recorded in the Mediterranean, and many of them have also been established in their own ecological niches [11]. The latest record of a marine mammal migrating from the Red Sea to the Mediterranean is that of the Indian humpback dolphin (Sousa plumbea) sighted both on Turkish coastal waters off the northeast Mediterranean and in Karavolas Bay, near the port of Heraklion, Crete, Greece $[12,13]$.

Even though these kind of migrants are very common in the Mediterranean, in recent years there have been instances where migrants that originate from the Atlantic Ocean have also been documented. In particular, Colloca [14] recorded the presence of two female tope sharks (Galeorhinus galeus) that were tagged in the north-east Atlantic and recaptured in the central Mediterranean Sea near Sicily. In addition, Scheinin [15] recorded the appearance of a gray whale (Eschrichtius robustus) near the Israeli Mediterranean shore and twentytwo days later, the same individual was sighted in Spanish Mediterranean waters. This particular sighting was quite interesting as gray whales were last recorded in the North Atlantic in the 1700s and this was the first time that such an individual was sighted in the Mediterranean. Recent studies seem to indicate that some fin whales (Balaenoptera physalus), believed to belong to the north-east North Atlantic (NENA) stock, now use the Strait of Gibraltar to travel between the Atlantic Ocean and the Mediterranean Sea [16]. Apart from marine mammals and fish that migrate from the Atlantic to the Mediterranean, other species belonging to the crustacean subphylum have also been recorded as such The Atlantic crab (Dyspanopeus sayi) has expanded to many Italian areas, the blue crab (Callinectes sapidus) to a lake in northern Greece and in the southern Adriatic Sea, the species Farfantepenaeus aztecus in the Ionian sea, and the American lobster (Homarus americanus) in the eastern Mediterranean [17-20]. There has also been evidence of the eel species Anguilla anguilla exiting the Mediterranean sea towards the Atlantic ocean [21]. This information can lead to conducting further research about the Mediterranean's new species migration status. The appearance of new species from the Atlantic to the Mediterranean could also lead to the transmission and spread of new pathogens that are not indigenous in the Mediterranean [22].

The first recorded pathogens could bring disastrous consequences on the health of the indigenous Mediterranean species. This was evident in the research of Papadopoulos et al. [23], where two nematodes belonging to the species Acanthocheilonema spirocauda were found in the right ventricle of the heart of a Mediterranean monk seal. This particular parasite has a global presence and has been found in numerous species of arctic pinnipeds such as Phoca hispida, Phoca vitulina, Phoca groenlandica, and Cystophora cristata [24,25]. Moreover, Komnenou et al. [26] recorded for the first time the presence of the hookworm Uncinaria hamiltoni in rehabilitated Mediterranean monk seal pups in Greece, suggesting a cosmopolitan distribution of the parasite in question, and a dynamic evolutionary spatial pattern of its host-parasite interaction.

Parasites are important components of water column ecosystems [27,28]. Even though the consequences of parasitic infections are often not too serious, they have the potential to cause health problems in mammals in the extend of breaking down their protective barriers and increasing their susceptibility to subsequent bacterial and viral infections [29,30]. Most of the parasites that infect pinnipeds target the lungs, the gastric system, and the heart, as they try to acquire valuable nutrients that are required for proper growth and maintenance of the host $[30,31]$.

The Mediterranean monk seal is considered to be an opportunistic predator as it is capable of feeding on a wide variety of marine species. The seals' diet mainly consists of benthopelagic fish that belong to the Congridae, Gadidae, Sparidae, and Scorpaenidae families, and also cephalopods of the Octopodidae and Sepiidae families [32-35]. The fact that its prey varies makes the Mediterranean monk seal prone to parasitic infections, as the species that it feeds upon work as paratenic hosts for such parasites. Most of the time, 
these parasites are transferred through consumption of an intermediate, or paratenic host that carries infective third-stage larvae (L3) and inhabits the gastric, intestinal, ectopic, and gastrointestinal tracts, as well as the heart and the lungs of the final host [36]. The Mediterranean monk seal acts as a host to a variety of parasites that reside in different parts of its body and consequently affect different aspects of its well-being. The parasites that have been detected in the body of the monk seal belong to the species Acanthocheilonema spirocauda, which is a heartworm, Anisakis pegreffii, Contracaecum osculatum, Leishmania infantum, and individuals that belong to the genus Diphyllobothrium, that are mainly found in the gastric and intestinal tracts, and the ectoparasite Lepidophthirus piriformis, that resides in the fur of the animal [23,37-40]

The life cycle of nematodes in pinnipeds has been examined only for a few species that belong to the genus Pseusoteranova spp., such as Pseusoterranova decipiens sensu stricto and Pseudoterranova krabbei, but we can assume that it is probably similar within pinniped species $[41,42]$. The seal worm has a complex life cycle that includes a free-living stage, and three hosts are required for the parasite to complete its life cycle. The eggs are excreted in the feces of a seal and sink and stick to the sea floor where they hatch into free-living larvae. A benthic invertebrate ingests the larvae [43]. After the infected invertebrate is eaten by a fish, the third stage is L3 larvae migration from the stomach of the fish into the muscle tissue. Fish are essential seal worm hosts, in that they participate in the temporal and spatial dispersal of the larvae, thereby increasing the likelihood of ingestion by definitive hosts. They also support significant larval growth, thus improving the parasite's ability to establish itself and survive to maturity in the gastrointestinal tract of the final host $[44,45]$. Larvae after their consumption of the final host are attached in clusters to the stomach wall and penetrate the fundic wall to the submucosa, while adults and immature nematodes, which have completed the final molt, are superficially embedded in the mucosa [44].

The aim of this study was to identify, clarify, and record without a doubt the nematode individuals that were found in the stomach of the stranded M. monachus in our laboratory and consequently explore the possible reasons that caused its appearance in the Mediterranean, as well as its potential impact on the indigenous population of the species inhabiting these waters.

\section{Material and Methods}

\subsection{Parasite Collection and Molecular Techniques}

During the anatomy of the stomach of the Mediterranean monk seal, two nematode individuals were obtained (Figure 1). Parasites were cleaned with saline buffer and preserved in a $70 \%$ ethanol solution for further analysis. DNA extraction was conducted with EXTRACTME DNA TISSUE KIT (BLIRT S.A., Gdańsk, Poland). PCR fragments were amplified using a universal primer pair targeting the cytochrome oxidase subunit I (COI) gene [46]. PCR reactions were performed in $25 \mu \mathrm{L}$ containing $10 \mathrm{ng}$ template DNA, $5 \mu \mathrm{L}$ of $10 \times$ PCR Buffer, $10 \mu \mathrm{L} \mathrm{MgCl} 2(25 \mathrm{mM}), 1 \mu \mathrm{L}$ of dNTPs $(10 \mathrm{mM}), 1.5 \mu \mathrm{L}$ each of forward and reverse primer $(10 \mu \mathrm{M})$, and $1 \mu \mathrm{L}$ Taq polymerase (KAPA —Sigma-Aldrich, Taufkirchen, Germany). PCR amplification was applied under the following cycling conditions: an initial denaturation at $95^{\circ} \mathrm{C}$ for $10 \mathrm{~min}$ followed by 35 cycles in a gradient thermocycler (LIFETOUCH, Laboran, Navarra, Spain). Each cycle included the steps below: a denaturation at $95{ }^{\circ} \mathrm{C}$ for $45 \mathrm{~s}$, an annealing at $50{ }^{\circ} \mathrm{C}$ for $30 \mathrm{~s}$, and an extension at $72{ }^{\circ} \mathrm{C}$ for $1 \mathrm{~min}$. A final extension at $72{ }^{\circ} \mathrm{C}$ for $10 \mathrm{~min}$ was applied. The PCR amplification products were separated in $1.5 \%$ (wt/vol) agarose gels using $1 \times$ Tris Borate EDTA (TBE) and photographed on a UV transilluminator (MiniBIS, DNR Bio-Imaging System Ltd., Jerusalem, Israel). All sequences were determined (Sanger sequencing) on an ABI PRISM ${ }^{\circledR} 3700$ DNA Analyzer (Applied Biosystems, Waltham, MA, USA). Each fragment used was sequenced in both directions in order to maximize the accuracy of the sequence. Further Figures can be found in Supplementary Material (Figures S1 and S2). 


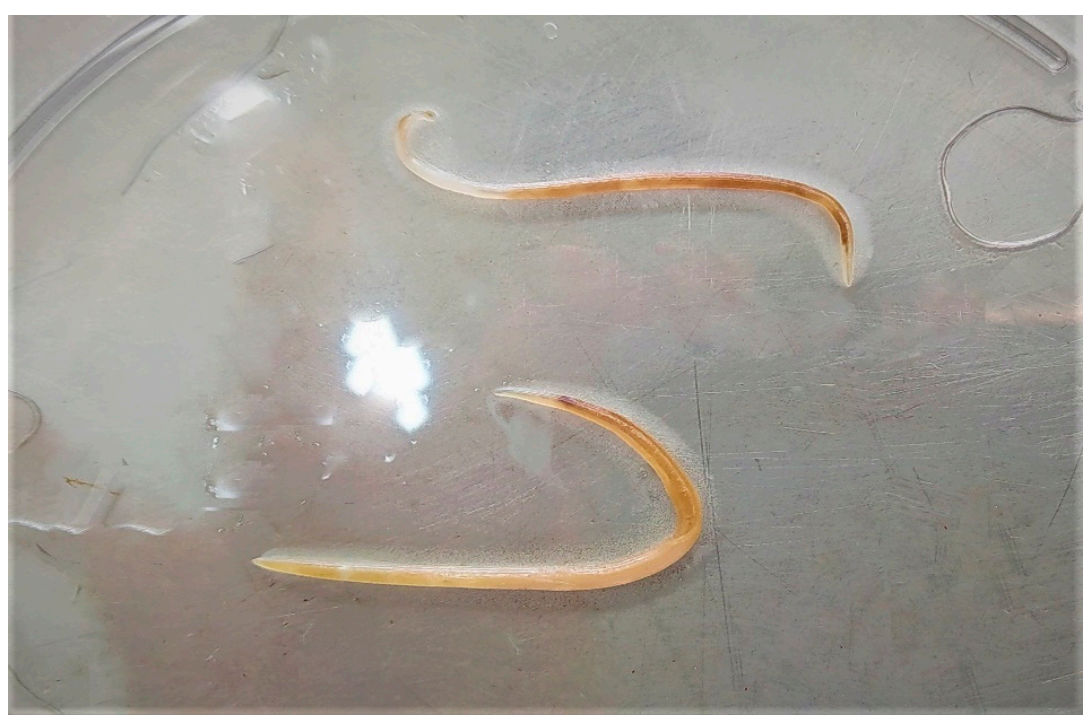

Figure 1. The two parasitic nematodes (at the bottom Individual 1 and at the upper Individual 2) that were obtained from the stomach contents of the Mediterranean monk seal (credits: Laboratory of Ichthyology and Hydrobiology, Dept. of Ichthyology and Aquatic Environment, University of Thessaly).

\subsection{Statistical Methods}

In order to infer phylogenetic relationships, the Bayesian inference (BI) model-based methods was used. MrBayes v.2.01 software was used for Bayesian inference [47]. The respective tree spaces were explored using four chains: one cold chain and subsequently three incrementally heated ones with temperature set at 0.20 . A GTR model [48] of sequence evolution was employed, allowing a gamma shape of among-site rate variation. Posterior probability distributions were obtained for the phylogenies and the parameters of the model of sequences' evolution were adjusted; random trees were used as seeds. Tree spaces were explored inferring 1,000,000 generations, with 100 generations sampled each time, and the burn-in was set to $25 \%$.

Analyses of pairwise divergence were conducted by estimating the number of base substitutions per site between species sequences and implementing the Kimura 2-parameter [49] correction in MEGA4 software [50]. The rate variation among sites was modeled with a gamma distribution (shape parameter 2).

\section{Results}

The morphological analysis of the parasites revealed the presence of two alive intact female individuals that were 4.8 (Individual 1) and $4.1 \mathrm{~cm}$ (Individual 2) in length, respectively. The amplified COI sequence revealed a length of $585 \mathrm{bp}$. Blast analysis through the NCBI GenBank established a $96 \%$ similarity with the species Pseudoterranova bulbosa. A Bayesian phylogenetic tree was constructed by utilizing ten Pseudoterranova sequences, one sequence of the outgroup Anisakis physeteris (Table 1) and the studied sequence of Pseudoterranova spp. Sequences were aligned by AliView (Alignment Viewer and Editor) [51]. The evolutionary relationships between the specimens and the other species of Pseudoterranova spp. are shown in the phylogenetic tree that was constructed (Figure 2). The highest sequence divergence value of the studied sequences was that recorded for the Pseudoterranova depiciens and the Pseudoterranova azarazi, whereas the lowest one was recorded for P. bulbosa comparison (Table 2). 
Table 1. Taxa used for phylogenetic analyses. OM037608 accession number were recently submitted to GenBank as an outcome of the present study.

\begin{tabular}{ccc}
\hline Classification & GenBank Accession Numbers & Reference \\
\hline Pseudoterranova decipiens & AJ891148 and AJ891149 & {$[52]$} \\
Pseudoterranova cattani & AJ891143 and MT941431 & {$[52,53]$} \\
Pseudoterranova azarasi & AJ891139 & \\
Pseudoterranova krabbei & LC312195 & {$[54]$} \\
Pseudoterranova bulbosa & AJ891152 and AJ891151 & {$[52]$} \\
Pseudoterranova spp. & NC031643 and KU558720 & {$[55]$} \\
Anisakis physeteris & OM037608 & this study \\
\hline
\end{tabular}

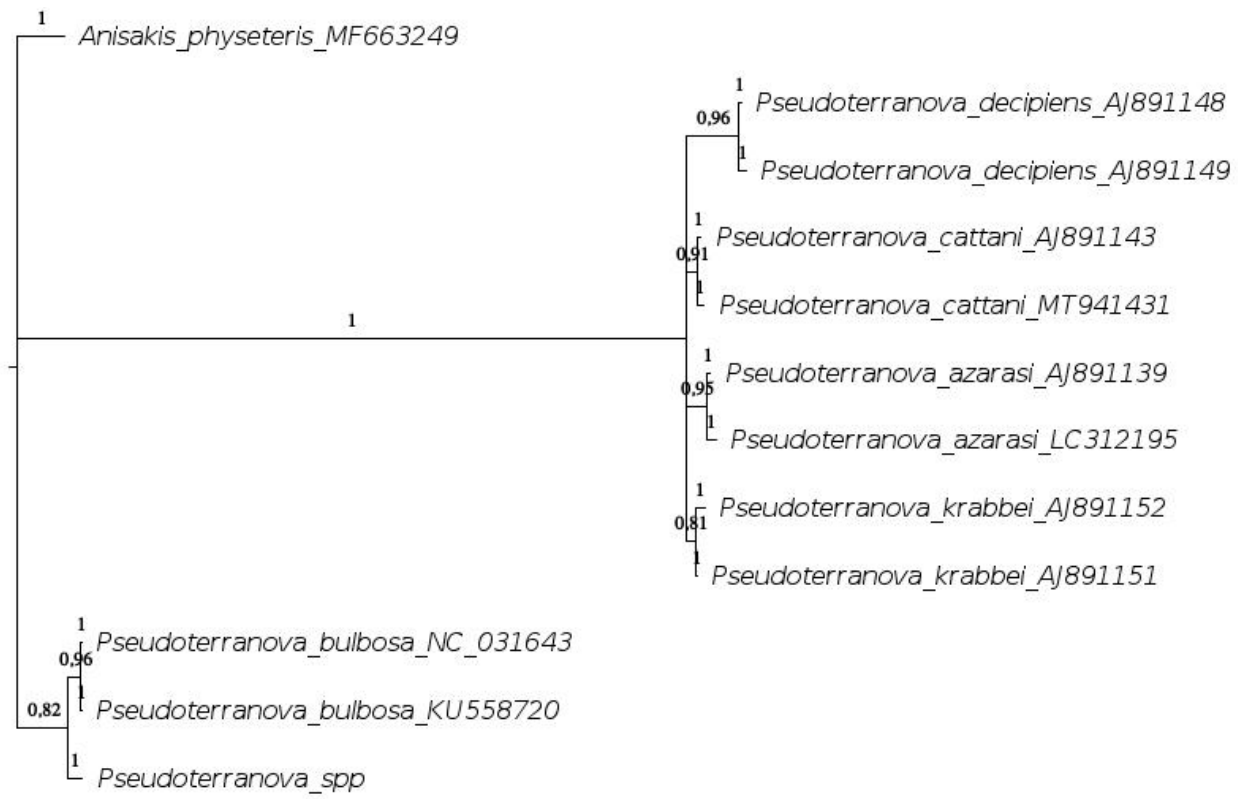

0.2

Figure 2. Phylogenetic tree generated from Bayesian Inference (BI) analysis of sequences of the COI gene. Values on the nodes indicate Bayesian Inference posterior probabilities.

Table 2. Estimates of evolutionary divergence over sequence pairs between the taxa used for the phylogenetic inference, indicating number of base substitutions per site.

\begin{tabular}{|c|c|c|c|c|c|c|c|c|c|c|c|}
\hline \multicolumn{12}{|l|}{ A. Physeteris_MF663249 } \\
\hline P. bulbosa_NC_031643 & 0.156 & & & & & & & & & & \\
\hline P. bulbosa_KU558720 & 0.156 & 0.000 & & & & & & & & & \\
\hline P. decipiens_AJ891148 & 2.682 & 1.994 & 1.994 & & & & & & & & \\
\hline P. decipiens_AJ891149 & 2.937 & 2.093 & 2.093 & 0.016 & & & & & & & \\
\hline P. cattani_AJ891143 & 2.600 & 1.836 & 1.836 & 0.112 & 0.119 & & & & & & \\
\hline P. cattani_MT941431 & 2.378 & 1.885 & 1.885 & 0.113 & 0.120 & 0.016 & & & & & \\
\hline P. azarasi_AJ891139 & 3.088 & 2.058 & 2.058 & 0.138 & 0.142 & 0.070 & 0.077 & & & & \\
\hline P. azarasi_LC312195 & 2.006 & 1.580 & 1.580 & 0.078 & 0.085 & 0.063 & 0.057 & 0.012 & & & \\
\hline P. krabbei_AJ891152 & 2.677 & 1.844 & 1.844 & 0.120 & 0.124 & 0.064 & 0.071 & 0.061 & 0.051 & & \\
\hline P. krabbei_AJ891151 & 2.677 & 1.726 & 1.726 & 0.109 & 0.120 & 0.049 & 0.055 & 0.055 & 0.044 & 0.016 & \\
\hline Pseudoterranova spp. & 0.162 & 0.042 & 0.042 & 1.994 & 2.093 & 1.880 & 1.913 & 2.058 & 1.505 & 1.844 & 1.726 \\
\hline
\end{tabular}

\section{Discussion}

\subsection{Parasitic Species Identification}

The clear-cut close evolutionary relationship between the studied species sequence and Pseudoterranova bulbosa (Cobb, 1888), indicates a documented possibility of the latter 
being present in the Mediterranean Sea. The P. decipiens complex is comprised of five sibling species. Phylogenetic analysis of specimens that have been isolated from several pinniped species has demonstrated significantly high genetic variation among sibling species; most of this genetic diversity is strongly structured between species, rather than within species [57]. The Pseudoterranova spp. has shown a wide-range geographic distribution with all five sibling species being present mostly in the Arctic regions. P. decipiens (Krabee, 1868) sensu stricto appear to have a wide geographical range that spans mainly Arctic and sub-Arctic regions, including the north-east Atlantic and Canadian Atlantic, and the Canadian Pacific waters [41,58-61], while its main pinniped hosts are the common seal (Phoca vitulina), the grey seal (Halichoerus grypus), and the species Phoca vitulina richardsii and Zalophus californianus [62]. On the other hand, P. azarasi [63] has a limited geographical distribution that expands mainly to Japanese, Sakhalinese waters, as well as the North Pacific Ocean, and its main definitive host is the Steller's sea lion Eumetopias jubatus [60]. P. krabbei [42] has been found to inhabit the north-east Atlantic Ocean and has as its definitive hosts the common and grey seal [41]. P. cattani [64] has been found near the Chilean coast and the species Otaria byronia acts as its definitive host [42]. At last, P. bulbosa (Cobb, 1888) appears to have a geographical distribution between the Barents and Norwegian Seas, the Canadian Atlantic and the Sea of Japan, while its main definitive host appears to be the bearded seal (Erignathus barbatus) $[41,59,60]$.

Based on the current bibliography and scientific records so far, the appearance of P. bulbosa in the Mediterranean Sea seems quite improbable. However, in our study molecular evidence clearly revealed that the Pseudoterranova spp. sequence was $>96 \%$ identical to that of P. bulbosa, found in Canadian waters [55], thus making the possibility of P. bulbosa being present in the stomach of our M. monachus individual-specimen quite probable, if not an undisputable fact. This assumption generates a series of questions of how this particular species came to colonize the stomach of a Mediterranean monk seal in our waters.

\subsection{Parasitic Dispersal}

One possible explanation for the appearance of the parasitic species in the stomach of the Mediterranean monk seal is that it has been transferred through consumption of an infected intermediate host. The dietary habits of M. monachus closely resemble those of the bearded seal as both species feed on similar organisms. Although the bearded seal mainly feeds on the bottom, with a few exceptions, and M. monachus has more diverse feeding grounds, they both feed on crustaceans, mollusks, cephalopods, especially squid, and fish $[33,65]$. In the probable appearance of a parasite such as P. bulbosa in the Mediterranean, the monk seal is the most predictable host, as it provides an infection cycle that most resembles that of the original, and also as the only pinniped in the Mediterranean Sea, it provides a known host to the parasite [44]. One such intermediate host could be Gadus morhua, as it has been found to be infected by this particular parasite and it also migrates well to the Mediterranean Sea [66,67]. It is widely known that fish constitute a vital part in the development and dissemination of the nematode parasites, as they provide shelter and ideal conditions for them to grow [45]. In addition, the parasitic nematodes that reside into cold waters are not particularly selective to their intermediate hosts, a behavior that helps them infect whichever host comes their way, as most parasites are selective only for their final host $[68,69]$.

Dispersal of the parasite may be due to environmental pressures, such as climate change, because it affects the distribution of the fish in the marine ecosystem changing biogeography and biodiversity and causing change in the food web, which can lead to fish searching for new feeding grounds and thus spreading the parasites to new hosts [70]. The de facto melting of the ice can also provide new migration patterns for marine mammals from northern to southern regions, making them susceptible to new parasitic infections [71].

Food global trade that supports the consumption of imported fishes might also be responsible for the geographic distribution of the nematode in question. Parasites of the genus Pseudoterranova spp. are the main causative agents of human pseudoterranoviasis 
that have become to affect for the first time the Mediterranean populations [58]. The Mediterranean monk seal is a species that feeds and resides in close proximity to shallow and coastal regions where anthropogenic pressure can affect its health and habitat [72].

\subsection{Genetic Relationships}

The molecular analysis of our nematode sequence Pseudoterranova spp. revealed a relatively low genetic distance between $A$. physeteris and $P$. bulbosa, which indicates a close evolutionary relationship and genetic similarity. The $A$. physeteris species is a nematode with a global distribution as it can be found in the Atlantic, Mediterranean, and South African waters. The main intermediate hosts of this specific parasite are fish belonging to the Kogiidae family. As final hosts, marine mammals that belong to the Physeteridae family, specifically the species Physeter macrocephalus, are considered the main host of the parasite [73]. This parasite has been also detected in other marine mammals such as Ziphius cavirostris and the pinniped Arctocephalus pusillus [74,75]. The A. physeteris species has been detected in fish and cephalopods such as the species Merluccius merluccius, Scomber scombrus, Phycis phycis, Phycis blennoides, Illex coindetii, Histioteuthis bonnellii, and Histioteuthis reversa, that constitute part of the prey of P. macrocephalus and M. monachus [75-77]. Considering this information, one could assume that the A. physeteris and P. bulbosa species followed a parallel evolution pattern. The cause for their divergence could be that individuals of the same species historically would infect hosts who possessed different biological characteristics and resided in different ecosystems. This assumption could possibly explain how these two species came to be so closely related, yet so geographically isolated. Considering the close evolutionary relationship between the nematode species $A$. physeteris and P. bulbosa, one could not dismiss the possibility that these two species could also coexist in the organism of certain marine mammals [74]. Such a possible host could be the sperm whale, which shares certain habitats with M. monachus (sperm whales travel from Crete to North Aegean and Ionian Sea, while Mediterranean monk seals are founds all over the Greek coastline of the same regions) [78]. On the other hand, in many studies so far, the identification of parasites is conducted mainly based on morphological standards; it has been well documented that visual examination when trying to identify a nematode of a species level is scientifically deficient [79]. Considering this and the fact that the sperm whale carries the parasitic nematode A. physeteris, it may be likely that the parasites found and recorded in the stomachs of stranded sperm whales did not only belong to the genus Anisakis, but they could have belonged to the genus Pseudoterranova as well [75]. The morphology of the different parasitic genera that make up the Anisakidae family is not fully known yet, due to the development of different larval stages that occur throughout the parasite's life cycle [80]. Identification can be further complicated by morphological characteristics that are shared by different genera, such as relative size, special shapes, differences between males and females, as well as the nematode head and tail shape; even the presence or absence of cuticular spicules on the body [81,82]. A. physeteris and Pseudoterranova spp. Are morphologically similar. This could mean that every time a parasite was found in the stomach of a sperm whale that was believed to be A. physeteris, it could well have been that of Pseudoterranova spp. Therefore, A. physeteris and Pseudoterranova spp. could coexist in the stomachs of marine mammals that appear to inhabit the same environment. Portes Santos [83], while examining the stomach contents of a pygmy sperm whale (Kogia breviceps) that was stranded in the north-eastern Coast of Brazil, found that parasites belonging to the species $A$. physeteris and genus Pseudoterranova were coexisting with the Pseudoterranova specimens being in an immature state. The parasites were identified based on morphological methods. Solís [84] also identified in the stomach contents of pygmy sperm whales an anisakid nematode belonging to the species Pseudoterranova ceticola. This could mean that Pseudoterranova genus use the sperm whale as a host and that it could transfer to other species of marine mammals when found in the same ecological niche.

On the other hand, estimates of transmission parameters are difficult and complicated, as they might be underestimated by possible indirect hosts. Holt [85] argued that trans- 
mission rates between species that compete for resources may also have a higher potential for interspecific pathogen transmission. At this point, the knowledge around the parasitic nematode $P$. bulbosa is limited.

\section{Management and Conservation Implications}

The presence of the genus Pseudoterranova spp. was reported for the first and only time in the Mediterranean. The appearance of a novel parasitic migrant in the population of the M. monachus species could potentially threaten its health, already imperiled by anthropogenic and abiotic factors, and alter the structure of its community [86-88]. The low genetic diversity of the species should also be considered as a factor that affects the relationship between the parasite and the host species [89]. The low genetic diversity of the species is closely linked to the inbreeding tendencies of the small and geographically isolated subpopulation, therefore it is unavoidable. Inbreeding, which increases homozygosity, is expected to compromise resistance against parasitism, as genetic diversity affects both short-term individual fitness and long-term population adaptive potential [90,91]. In fact, many studies on Heterozygosity Fitness Correlations (HFCs) have shown a clear correlation between genomic diversity and fitness as heterozygous individuals are less likely to be infected by a range of parasites [91,92]. The Mediterranean monk seal appears to be one of the most genetically depauperate marine mammals on Earth [89] and therefore it is understandable that the current population structure observed in the monk seal has the potential to influence the relationships between the species and parasites $[89,93]$.

It is evident that urgent conservation efforts must be made to protect the $M$. monachus subpopulation, by enhancing existing protection methods and enlisting new molecular practices that could potentially be of use in rehabilitation, and parasitological surveys that are essential for preventing the emergence of novel diseases, thus consequently helping the survival of the species [26].

The relationship between hosts and parasites represents a critical issue for wildlife conservation [26] and even though the study of parasites in wild marine hosts is challenging, further research on the parasitic impact in relation to the health status of animals must be conducted, as it is a critical step towards the implementation of appropriate management plans for their protection [94].

Supplementary Materials: The following are available online at https:/ / www.mdpi.com/article / 10.3390 / conservation2010010/s1, Figure S1: DNA extraction of the two individuals (Ind1 and Ind2) using the standard phenol/chloroform protocol. The Ladder is at $1 \mathrm{~Kb}$ per lane, Figure S2: PCR of the $585 \mathrm{bp}$ amplified product of the Cytochrome oxidase subunit I gene for the two individuals (Ind1 and Ind2) including a negative control (N). The Ladder is at $100 \mathrm{bp}$ per lane.

Author Contributions: Conceptualization, G.A.G., A.K. and A.E.; methodology, E.K., J.S. and G.A.G.; software, E.K., G.A.G., J.S. and A.E.; validation, A.K., P.D., E.P. and A.E.; formal analysis, E.K., G.A.G. and A.E.; investigation, A.K., E.P., A.E. and G.A.G.; resources, G.A.G. and A.E.; data curation, E.K., J.S. and G.A.G.; writing—original draft preparation, E.K. and G.A.G.; writing—review and editing, A.K., P.D., E.P. and A.E.; visualization, G.A.G.; supervision, G.A.G.; project administration, G.A.G.; funding acquisition, A.E. All authors have read and agreed to the published version of the manuscript.

Funding: This research received no external funding.

Institutional Review Board Statement: Not applicable.

Informed Consent Statement: Not applicable.

Data Availability Statement: The data used in this study is available online: https:/ /www.ncbi.nlm. nih.gov / nuccore/OM037608 (accessed on 27 December 2021).

Acknowledgments: Authors would like to thank Warrant-Officer Rigas Kolentis (Hellenic Coast Guard) for his full support on transferring the animal to the facilities of the Laboratory of Ichthyology and Hydrobiology, Dept. Of Ichthyology and Aquatic Environment, University of Thessaly, Volos, Greece. 
Conflicts of Interest: The authors declare no conflict of interest.

\section{References}

1. Karamanlidis, A.A.; Dendrinos, P.; de Larrinoa, P.F.; Gücü, A.C.; Johnson, W.M.; Kiraç, C.O.; Pires, R. The Mediterranean Monk Seal M Onachus Monachus: Status, Biology, Threats, and Conservation Priorities: The Mediterranean Monk Seal. Mammal Rev. 2016, 46, 92-105. [CrossRef]

2. Pires, R.; Neves, H.C.; Karamanlidis, A.A. The Critically Endangered Mediterranean Monk Seal Monachus monachus in the Archipelago of Madeira: Priorities for Conservation. Oryx 2008, 42, 278-285. [CrossRef]

3. González, L.M.; Cedenilla, M.A.; de Larrinoa, P.F.; Layna, J.F.; Aparicio, F. Changes in the Breeding Variables of the Mediterranean Monk Seal (Monachus monachus) Colony of Cabo Blanco Peninsula after a Mass Mortality Episode. Mammalia 2002, 66, 173-182. [CrossRef]

4. Martínez-Jauregui, M.; Tavecchia, G.; Cedenilla, M.; Coulson, T.; Fernández de Larrinoa, P.; Muñoz, M.; González, L. Population Resilience of the Mediterranean Monk Seal Monachus monachus at Cabo Blanco Peninsula. Mar. Ecol. Prog. Ser. 2012, 461, 273-281. [CrossRef]

5. Dendrinos, P.; Karamanlidis, A.A.; Kotomatas, S.; Paravas, V.; Adamantopoulou, S. Report of a New Mediterranean Monk Seal (Monachus monachus) Breeding Colony in the Aegean Sea, Greece. Aquat. Mamm. 2008, 34, 355-361. [CrossRef]

6. Gucu, A.C.; Gucu, G.; Orek, H. Habitat Use and Preliminary Demographic Evaluation of the Critically Endangered Mediterranean Monk Seal (Monachus monachus) in the Cilician Basin (Eastern Mediterranean). Biol. Conserv. 2004, 116, 417-431. [CrossRef]

7. Güçlüsoy, H. Status of the Mediterranean Monk Seal, Monachus monachus (Hermann, 1779) in the Coastal Waters of Turkey. Ege J. Fish. Aquat. Sci. 2004, 21, 201-210.

8. Adamantopoulou, S.; Androukaki, E.; Dendrinos, P.; Kotomatas, S.; Paravas, V.; Psaradellis, M.; Tounta, E.; Karamanlidis, A. Movements of Mediterranean Monk Seals (Monachus monachus) in the Eastern Mediterranean Sea. Aquat. Mamm. 2011, 37, 256. [CrossRef]

9. Pool, R.; Chandradeva, N.; Gkafas, G.; Raga, J.A.; Fernández, M.; Aznar, F.J. Transmission and Predictors of Burden of Lungworms of the Striped Dolphin (Stenella coeruleoalba) in the Western Mediterranean. J. Wildl. Dis. 2019, 56, 186-191. [CrossRef]

10. Golani, D. Impact of Red Sea Fish Migrants through the Suez Canal on the Aquatic Environment of the Eastern Mediterranean. Bull. Ser. Yale Sch. For. Environ. Stud. 1998, 103, 375-387.

11. Rilov, G.; Galil, B. Marine Bioinvasions in the Mediterranean Sea-History, Distribution and Ecology. In Biological Invasions in Marine Ecosystems; Springer: Berlin/Heidelberg, Germany, 2009; pp. 549-575.

12. Özbilgin, Y.; Kalecik, E.; Gücü, A.C. First Record of Humpback Dolphins in Mersin Bay, the Eastern Mediterranean, Turkey. Turk. J. Fish. Aquat. Sci. 2018, 18, 187-190. [CrossRef]

13. Frantzis, A. A Long and Deep Step in Range Expansion of an Alien Marine Mammal in the Mediterranean: First Record of the Indian Ocean Humpback Dolphin Sousa plumbea (G. Cuvier, 1829) in the Greek Seas. BioInvasions Rec. 2018, 7, 83-87. [CrossRef]

14. Colloca, F.; Scannella, D.; Geraci, M.L.; Falsone, F.; Batista, G.; Vitale, S.; Di Lorenzo, M. British Sharks in Sicily: Records of Long Distance Migration of Tope Shark (Galeorhinus Galeus) from North-Eastern Atlantic to Mediterranean Sea. Mediterr. Mar. Sci. 2019, 20, 309-313. [CrossRef]

15. Scheinin, A.P.; Kerem, D.; MacLeod, C.D.; Gazo, M.; Chicote, C.A.; Castellote, M. Gray Whale (Eschrichtius robustus) in the Mediterranean Sea: Anomalous Event or Early Sign of Climate-Driven Distribution Change? Mar. Biodivers. Rec. 2011, 4, e28. [CrossRef]

16. Gauffier, P.; Verborgh, P.; Giménez, J.; Esteban, R.; Sierra, J.M.S.; de Stephanis, R. Contemporary Migration of Fin Whales through the Strait of Gibraltar. Mar. Ecol. Prog. Ser. 2018, 588, 215-228. [CrossRef]

17. Kapiris, K.; Apostolidis, C.; Baldacconi, R.; Başusta, N.; Bilecenoglu, M.; Bitar, G.; Bobori, D.; Boyaci, Y.Ö.; Dimitriadis, C.; Djurović, M. New Mediterranean Biodiversity Records (April, 2014). Mediterr. Mar. Sci. 2014, 15, 198-212. [CrossRef]

18. Beqiraj, S.; Kashta, L. The Establishment of Blue Crab Callinectes sapidus Rathbun, 1896 in the Lagoon of Patok, Albania (South-East Adriatic Sea). Aquat. Invasions 2010, 5, 219-221. [CrossRef]

19. Deval, M.C.; Kaya, Y.; Güven, O.; Gökoğlu, M.; Froglia, C. An Unexpected Find of the Western Atlantic Shrimp, Farfantepenaeus Aztecus (Ives, 1891) (Decapoda, Penaeidae) in Antalya Bay, Eastern Mediterranean Sea. Crustaceana 2010, 83, $1531-1537$.

20. Kampouris, T.E.; Gkafas, G.A.; Sarantopoulou, J.; Exadactylos, A.; Batjakas, I.E. An American in the Aegean: First Record of the American Lobster Homarus Americanus, H. Milne Edwards, 1837 from the Eastern Mediterranean Sea. BioInvasions Rec. 2021, in press. [CrossRef]

21. Amilhat, E.; Aarestrup, K.; Faliex, E.; Simon, G.; Westerberg, H.; Righton, D. First Evidence of European Eels Exiting the Mediterranean Sea during Their Spawning Migration. Sci. Rep. 2016, 6, 1-9. [CrossRef]

22. Dunn, A.M.; Hatcher, M.J. Parasites and Biological Invasions: Parallels, Interactions, and Control. TRENDS Parasitol. 2015, 31, 189-199. [CrossRef] [PubMed]

23. Papadopoulos, E.; Loukopoulos, P.; Komnenou, A.; Androukaki, E.; Karamanlidis, A. First Report of Acanthocheilonema Spirocauda in the Mediterranean Monk Seal (Monachus monachus). J. Wildl. Dis. 2010, 46, 570-573. [CrossRef] [PubMed]

24. ELEY, T.J. Dipetalonema spirocauda in Alaskan marine mammals. J. Wildl. Dis. 1981, 17, 65-67. [CrossRef] [PubMed]

25. Measures, L.N.; Gosselin, J.-F.; Bergeron, E. Heartworm, Acanthocheilonema spirocauda (Leidy, 1858), Infections in Canadian Phocid Seals. Available online: https:/ /cdnsciencepub.com/doi/10.1139/f96-342 (accessed on 27 December 2021). 
26. Komnenou, A.T.; Gkafas, G.A.; Kofidou, E.; Sarantopoulou, J.; Exadactylos, A.; Tounta, E.; Koemtzopoulos, K.; Dendrinos, P.; Karamanlidis, A.A.; Gulland, F.; et al. First Report of Uncinaria hamiltoni in Orphan Eastern Mediterranean Monk Seal Pups in Greece and Its Clinical Significance. Pathogens 2021, 10, 1581. [CrossRef]

27. Hudson, P.J.; Dobson, A.P.; Lafferty, K.D. Is a Healthy Ecosystem One That Is Rich in Parasites? Trends Ecol. Evol. 2006, 21, 381-385. [CrossRef]

28. Thompson, R.; Lymbery, A.; Smith, A. Parasites, Emerging Disease and Wildlife Conservation. Int. J. Parasitol. 2010, 40, 1163-1170. [CrossRef]

29. Anderson, R.M.; May, R.M. Population Biology of Infectious Diseases: Part, I. Nature 1979, 280, 361-367. [CrossRef]

30. Vos, J.G.; Bossart, G.; Fournier, M.; O'Shea, T. Toxicology of Marine Mammals; CRC Press: Boca Raton, FL, USA, 2002.

31. Stroud, R.K.; Dailey, M.D. Parasites and Associated Pathology Observed in Pinnipeds Stranded along the Oregon Coast. J. Wildl. Dis. 1978, 14, 292-298. [CrossRef]

32. Salman, A.; Bilecenoglu, M.; Güçlüsoy, H. Stomach Contents of Two Mediterranean Monk Seals (Monachus monachus) from the Aegean Sea, Turkey. J. Mar. Biol. Assoc. UK 2001, 81, 719-720. [CrossRef]

33. Pierce, G.J.; Hernandez-Milian, G.; Santos, M.B.; Dendrinos, P.; Psaradellis, M.; Tounta, E.; Androukaki, E.; Edridge, A. Diet of the Monk Seal (Monachus monachus) in Greek Waters. Aquat. Mamm. 2011, 37, 284. [CrossRef]

34. Kıraç, C.O.; Ok, M. Diet of a Mediterranean Monk Seal Monachus monachus in a Transitional Post-Weaning Phase and Its Implications for the Conservation of the Species. Endanger. Species Res. 2019, 39, 315-320. [CrossRef]

35. Karamanlidis, A.A.; Kallianiotis, A.; Psaradellis, M.; Adamantopoulou, S. Stomach Contents of a Subadult Mediterranean Monk Seal (Monachus monachus) from the Aegean Sea. Aquat. Mamm. 2011, 37, 280. [CrossRef]

36. Mattiucci, S.; Cipriani, P.; Levsen, A.; Paoletti, M.; Nascetti, G. Molecular Epidemiology of Anisakis and Anisakiasis: An Ecological and Evolutionary Road Map. In Advances in Parasitology; Elsevier: Amsterdam, The Netherlands, 2018; Volume 99, pp. 93-263. [CrossRef]

37. Campana-Rouget, Y. Sur deux nouveaux genres de Spirurides parasites de Poissons; Discussion systématique des genres voisins. Ann. Parasitol. Hum. Comparée 1955, 30, 346-362. [CrossRef]

38. Schnapp, B.; Hellwing, S.; Ghizelea, G. Contributions to the Knowledge of the Black Sea Seal (Monachus monachus) Herm. Trav. Mus. D'Histoire Nat. Gr. Antipa 1962, 3, 383-400.

39. Blagoveshtchensky, D. New Forms of Lice (Siphunculata) Parasites of Pinnipeds and Hares. Rev. Entom URSS 1966, 45, 806-813.

40. Mackiewicz, J.S. Cestode Transmission Patterns. J. Parasitol. 1988, 74, 60-71. [CrossRef]

41. Paggi, L.; Nascetti, G.; Cianchi, R.; Orecchia, P.; Mattiucci, S.; D’Amelio, S.; Berland, B.; Brattey, J.; Smith, J.; Bullini, L. Genetic Evidence for Three Species within Pseudoterranova decipiens (Nematoda, Ascaridida, Ascaridoidea) in the North Atlantic and Norwegian and Barents Seas. Int. J. Parasitol. 1991, 21, 195-212. [CrossRef]

42. Paggi, L.; Mattiucci, S.; Gibson, D.I.; Berland, B.; Nascetti, G.; Cianchi, R.; Bullini, L. Pseudoterranova Decipiens Species A and B (Nematoda, Ascaridoidea): Nomenclatural Designation, Morphological Diagnostic Characters and Genetic Markers. Syst. Parasitol. 2000, 45, 185-197. [CrossRef]

43. Lunneryd, S.-G.; Boström, M.K.; Aspholm, P.E. Sealworm (Pseudoterranova decipiens) Infection in Grey Seals (Halichoerus grypus), Cod (Gadus morhua) and Shorthorn Sculpin (Myoxocephalus scorpius) in the Baltic Sea. Parasitol. Res. 2015, 114, 257-264. [CrossRef]

44. McClelland, G. The Trouble with Sealworms (Pseudoterranova decipiens Species Complex, Nematoda): A Review. Parasitology 2002, 124, 183-203. [CrossRef]

45. Martell, D.; McClelland, G. Transmission of Pseudoterranova decipiens (Nematoda: Ascaridoidea) via Benthic Macrofauna to Sympatric Flatfishes (Hippoglossoides platessoides, Pleuronectes ferrugineus, P. americanus) on Sable Island Bank, Canada. Mar. Biol. 1995, 122, 129-135. [CrossRef]

46. Folmer, O.; Black, M.; Hoeh, W.; Lutz, R.; Vrijenhoek, R. DNA Primers for Amplification of Mitochondrial Cytochrome c Oxidase Subunit I from Diverse Metazoan Invertebrates. Mol. Mar. Biol Biotechnol 1994, 3, 294-299. [PubMed]

47. Huelsenbeck, J.P.; Ronquist, F. MRBAYES: Bayesian Inference of Phylogenetic Trees. Bioinformatics 2001, 17, 754-755. [CrossRef]

48. Tavaré, S. Some Probabilistic and Statistical Problems in the Analysis of DNA Sequences. Lect. Math. Life Sci. 1986, 17, 57-86.

49. Kimura, M. A Simple Method for Estimating Evolutionary Rates of Base Substitutions through Comparative Studies of Nucleotide Sequences. J. Mol. Evol. 1980, 16, 111-120. [CrossRef] [PubMed]

50. Tamura, K.; Dudley, J.; Nei, M.; Kumar, S. MEGA4: Molecular Evolutionary Genetics Analysis (MEGA) Software Version 4.0. Mol. Biol. Evol. 2007, 24, 1596-1599. [CrossRef]

51. Larsson, A. AliView: A Fast and Lightweight Alignment Viewer and Editor for Large Datasets. Bioinformatics 2014, 30, 3276-3278. [CrossRef]

52. Cao, Z.; Zhu, X.Z.Q.; Weng, Y.-B.; Lin, R.-Q.; Li, M.-W.; Zou, F.C.; He, F. Polymorphisms in Mitochondrial LsrRNA and Cox1 Genes within and between Members of Pseudoterranova decipiens Complex. Chin. Vet. J. 2005, 25, 600-603.

53. Ebmer, D.; Navarrete, M.J.; Muñoz, P.; Flores, L.M.; Gärtner, U.; Brabec, J.; Poppert, S.; Taubert, A.; Hermosilla, C. Anthropozoonotic Parasites Circulating in Synanthropic and Pacific Colonies of South American Sea Lions (Otaria flavescens): Non-Invasive Techniques Data and a Review of the Literature. Front. Mar. Sci. 2020, 847. [CrossRef]

54. Tokoro, M.; Yamaguchi, H.; Ito, Y.; Mizuno, T.; Mitsuboshi, A.; Kasai, M. Extra-Gastrointestinal Anisakidosis Caused by Pseudoterranova azarasi Manifesting as Strangulated Inguinal Hernia. Parasitol. Int. 2017, 66, 810-812. 
55. Liu, G.-H.; Nadler, S.A.; Liu, S.-S.; Podolska, M.; D'Amelio, S.; Shao, R.; Gasser, R.B.; Zhu, X.-Q. Mitochondrial Phylogenomics Yields Strongly Supported Hypotheses for Ascaridomorph Nematodes. Sci. Rep. 2016, 6, 39248. [CrossRef] [PubMed]

56. Quiazon, K.M.A.; Hill-Spanik, K.M.; Denson, M.R.; de Buron, I. Identification and Distribution of Ascaridoid Larvae in Marine Fishes from Inshore and Offshore Waters along the Coast of South Carolina, USA; Grice Marine Lab, College of Charleston: 205 Fort Johnson Road, Charleston, SC, USA, 2017.

57. Mattiucci, S.; Nascetti, G. Chapter 2 Advances and Trends in the Molecular Systematics of Anisakid Nematodes, with Implications for Their Evolutionary Ecology and Host-Parasite Co-Evolutionary Processes. In Advances in Parasitology; Academic Press: Cambridge, MA, USA, 2008; Volume 66, pp. 47-148. [CrossRef]

58. Cavallero, S.; Scribano, D.; D'Amelio, S. First Case Report of Invasive Pseudoterranoviasis in Italy. Parasitol. Int. 2016, 65, 488-490. [CrossRef] [PubMed]

59. Brattey, J.; Stenson, G.B. Host Specificity and Abundance of Parasitic Nematodes (Ascaridoidea) from the Stomachs of Five Phocid Species from Newfoundland and Labrador. Can. J. Zool. 1993, 71, 2156-2166. [CrossRef]

60. Mattiucci, S.; Paggi, L.; Nascetti, G.; Ishikura, H.; Kikuchi, K.; Sato, N.; Cianchi, R.; Bullini, L. Allozyme and Morphological Identification of Shape Anisakis, Contracaecum and Pseudoterranova from Japanese Waters (Nematoda, Ascaridoidea). Syst. Parasitol. 1998, 40, 81-92. [CrossRef]

61. Nadler, S.A.; D'Amelio, S.; Dailey, M.D.; Paggi, L.; Siu, S.; Sakanari, J.A. Molecular Phylogenetics and Diagnosis of Anisakis, Pseudoterranova, and Contracaecum from Northern Pacific Marine Mammals. J. Parasitol. 2005, 91, 1413-1429. [CrossRef]

62. Paggi, L.; Mattiucci, S.; D'Amelio, S.; Nascetti, G. Nematodi Del Genere Anisakis in Pesci, Cefalopodi e Cetacei Del Mar Mediterraneo e Dell'Oceano Atlantico e Pacifico. Biol. Mar. Mediterr. 1998, 5, 1585-1592.

63. Yamaguti, S.; Arima, S. Porrocaecum azarasi n. sp. (Nematoda) from the Japanese Seal. Trans. Sapporo Nat. Hist. Soc. 1942, 17, 113-116.

64. George-Nascimento, M.; Urrutia, X. Pseudoterranova cattani sp. nov. (Ascaridoidea: Anisakidae), Un Parásito Del Lobo Marino Común Otaria Byronia De Blainville En Chile. Rev. Chil. Hist. Nat. 2000, 73, 93-98. [CrossRef]

65. Finley, K.J.; Evans, C. Summer Diet of the Bearded Seal (Erignathus barbatus) in the Canadian High Arctic. Arctic 1983, 36, 82-89. [CrossRef]

66. Jørgensen, C.; Dunlop, E.S.; Opdal, A.F.; Fiksen, Ø. The Evolution of Spawning Migrations: State Dependence and Fishing-induced Changes. Ecology 2008, 89, 3436-3448. [CrossRef]

67. Morey, G.; Morales-Nin, B.; Riera, F.; Grau, A.; Geffen, A.J.; Pérez-Mayol, S.; Chang, M.-Y.; Grau, A.M. Atlantic Cod Gadus morhua in the Mediterranean: A Surprising Immigrant. Mar. Ecol. Prog. Ser. 2012, 467, 277-280. [CrossRef]

68. Holmes, J.C. Helminth Communities in Marine Fishes. In Parasite Communities: Patterns and Processes; Springer: Berlin/Heidelberg, Germany, 1990; pp. 101-130.

69. Alt, K.G.; Kochmann, J.; Klimpel, S.; Cunze, S. Improving Species Distribution Models of Zoonotic Marine Parasites. Sci. Rep. 2019, 9, 9851.

70. Marcogliese, D.J. Food Webs and the Transmission of Parasites to Marine Fish. Parasitology 2002, 124, 83-99. [CrossRef] [PubMed]

71. Learmonth, J.A.; MacLeod, C.D.; Santos, M.B.; Pierce, G.J.; Crick, H.; Robinson, R. Potential Effects of Climate Change on Marine Mammals. Oceanogr. Mar. Biol. 2006, 44, 431.

72. Fiorenza, E.A.; Wendt, C.A.; Dobkowski, K.A.; King, T.L.; Pappaionou, M.; Rabinowitz, P.; Samhouri, J.F.; Wood, C.L. It'sa Wormy World: Meta-analysis Reveals Several Decades of Change in the Global Abundance of the Parasitic Nematodes Anisakis spp. and Pseudoterranova spp. in Marine Fishes and Invertebrates. Glob. Change Biol. 2020, 26, 2854-2866. [CrossRef] [PubMed]

73. Hermosilla, C.; Hirzmann, J.; Silva, L.; Brotons, J.; Cerdà, M.; Prenger-Berninghoff, E.; Ewers, C.; Taubert, A. Occurrence of Anthropozoonotic Parasitic Infections and Faecal Microbes in Free-Ranging Sperm Whales (Physeter macrocephalus) from the Mediterranean Sea. Parasitol. Res. 2018, 117, 2531-2541. [CrossRef]

74. Stewardson, C.L.; Fourie, H. Endoparasites of the Cape Fur Seal Arctocephalus Pusillus Pusillus from the Eastern Cape Coast of South Africa. Trans. R. Soc. South. Afr. 1998, 53, 33-51. [CrossRef]

75. Mattiucci, S.; Paggi, L.; Nascetti, G.; Abollo, E.; Webb, S.; Pascual, S.; Cianchi, R.; Bullini, L. Genetic Divergence and Reproductive Isolation between Anisakis brevispiculata and Anisakis physeteris (Nematoda: Anisakidae) s. Int. J. Parasitol. 2001, 31, 9-14. [CrossRef]

76. Farjallah, S.; Slimane, B.B.; Busi, M.; Paggi, L.; Amor, N.; Blel, H.; Said, K.; D’Amelio, S. Occurrence and Molecular Identification of Anisakis spp. from the North African Coasts of Mediterranean Sea. Parasitol. Res. 2008, 102, 371-379. [CrossRef]

77. Palomba, M.; Mattiucci, S.; Crocetta, F.; Osca, D.; Santoro, M. Insights into the Role of Deep-Sea Squids of the Genus Histioteuthis (Histioteuthidae) in the Life Cycle of Ascaridoid Parasites in the Central Mediterranean Sea Waters. Sci. Rep. 2021, 11, 7135. [CrossRef]

78. Frantzis, A.; Swift, R.; Gillespie, D.; Menhennett, C.; Gordon, J.; Gialinakis, S. Sperm Whale Presence off Southwest Crete, Greece, Eastern Mediterranean. Eur Res. Cet 1999, 13, 214-217.

79. Shamsi, S.; Ghadam, M.; Suthar, J.; Mousavi, H.E.; Soltani, M.; Mirzargar, S. Occurrence of Ascaridoid Nematodes in Selected Edible Fish from the Persian Gulf and Description of Hysterothylacium Larval Type XV and Hysterothylacium persicum n. sp. (Nematoda: Raphidascarididae). Int. J. Food Microbiol. 2016, 236, 65-73. [CrossRef] [PubMed]

80. Berland, B. Nematodes from Some Norwegian Marine Fishes. Sarsia 1961, 2, 1-50. [CrossRef] 
81. Baptista-Fernandes, T.; Rodrigues, M.; Castro, I.; Paixão, P.; Pinto-Marques, P.; Roque, L.; Belo, S.; Ferreira, P.M.; Mansinho, K.; Toscano, C. Human Gastric Hyperinfection by Anisakis simplex: A Severe and Unusual Presentation and a Brief Review. Int. J. Infect. Dis. 2017, 64, 38-41. [CrossRef] [PubMed]

82. Nagasawa, K. The Life Cycle of Anisakis simplex: A Review. Intest. Anisakiasis Jpn. 1990, 31-40. [CrossRef]

83. Portes Santos, C.; Lodi, L. Occurrence of Anisakis Physeteris Baylis, 1923 and Pseudoterranova sp. (Nematoda) in Pygmy Sperm Whale Kogia Breviceps (De Blainvillei, 1838) (Physeteridae) in Northeastern Coast of Brazil. Mem. Inst. Oswaldo Cruz 1998, 93 , 187-188. [CrossRef]

84. Solís, D.G.; Vidal-Martínez, V.; Antochiw-Alonso, D.; Ortega-Argueta, A. Anisakid Nematodes from Stranded Pygmy Sperm Whales, Kogia breviceps (Kogiidae), in Three Localities of the Yucatan Peninsula, Mexico. J. Parasitol. 2006, 92, 1120-1122. [CrossRef]

85. Holt, R.D.; Dobson, A.P.; Begon, M.; Bowers, R.G.; Schauber, E.M. Parasite Establishment in Host Communities; Wiley: Hoboken, NJ, USA, 2003.

86. $\quad$ Langwig, K.E.; Voyles, J.; Wilber, M.Q.; Frick, W.F.; Murray, K.A.; Bolker, B.M.; Collins, J.P.; Cheng, T.L.; Fisher, M.C.; Hoyt, J.R. Context-dependent Conservation Responses to Emerging Wildlife Diseases. Front. Ecol. Environ. 2015, 13, 195-202. [CrossRef]

87. Karamanlidis, A.A.; Androukaki, E.; Adamantopoulou, S.; Chatzispyrou, A.; Johnson, W.M.; Kotomatas, S.; Papadopoulos, A.; Paravas, V.; Paximadis, G.; Pires, R. Assessing Accidental Entanglement as a Threat to the Mediterranean Monk Seal Monachus monachus. Endanger. Species Res. 2008, 5, 205-213. [CrossRef]

88. Formigaro, C.; Karamanlidis, A.A.; Dendrinos, P.; Marsili, L.; Silvi, M.; Zaccaroni, A. Trace Element Concentrations in the Mediterranean Monk Seal (Monachus monachus) in the Eastern Mediterranean Sea. Sci. Total Environ. 2017, 576, 528-537. [CrossRef]

89. Karamanlidis, A.A.; Gaughran, S.; Aguilar, A.; Dendrinos, P.; Huber, D.; Pires, R.; Schultz, J.; Skrbinšek, T.; Amato, G. Shaping Species Conservation Strategies Using MtDNA Analysis: The Case of the Elusive Mediterranean Monk Seal (Monachus monachus). Biol. Conserv. 2016, 193, 71-79. [CrossRef]

90. Luong, L.; Heath, B.; Polak, M. Host Inbreeding Increases Susceptibility to Ectoparasitism. J. Evol. Biol. 2007, 20, 79-86. [CrossRef] [PubMed]

91. Gkafas, G.A.; de Jong, M.; Exadactylos, A.; Raga, J.A.; Aznar, F.J.; Hoelzel, A.R. Sex-Specific Impact of Inbreeding on Pathogen Load in the Striped Dolphin. Proc. R. Soc. B 2020, 287, 20200195. [CrossRef]

92. Acevedo-Whitehouse, K.; Petetti, L.; Duignan, P.; Castinel, A. Hookworm Infection, Anaemia and Genetic Variability of the New Zealand Sea Lion. Proc. R. Soc. B Biol. Sci. 2009, 276, 3523-3529. [CrossRef] [PubMed]

93. Karamanlidis, A.A.; Skrbinšek, T.; Amato, G.; Dendrinos, P.; Gaughran, S.; Kasapidis, P.; Kopatz, A.; Stronen, A.V. Genetic and Demographic History Define a Conservation Strategy for Earth's Most Endangered Pinniped, the Mediterranean Monk Seal Monachus monachus. Sci. Rep. 2021, 11, 373.

94. Harvell, D.; Altizer, S.; Cattadori, I.M.; Harrington, L.; Weil, E. Climate Change and Wildlife Diseases: When Does the Host Matter the Most? Ecology 2009, 90, 912-920. [CrossRef] 